\title{
Association between angiotensin-1 converting enzyme gene polymorphism and the metabolic syndrome in a Mexican population
}

\author{
Cleto Alvarez-Aguilar ${ }^{1,7}$, \\ Maria Lucia Enríquez-Ramírez ${ }^{1}$, \\ Benigno Figueroa-Nuñez ${ }^{1}$, \\ Anel Gómez-García ${ }^{1,2}$, \\ Ernesto Rodríguez-Ayala ${ }^{1}$, \\ Cristina Morán-Moguel ${ }^{3}$, \\ Victor Manuel Farías-Rodríguez ${ }^{4}$, \\ Dolores Mino-León ${ }^{5}$ and \\ Joel Edmundo López-Meza ${ }^{6}$ \\ ${ }^{1}$ Unidad de Investigación en Epidemiología Clínica \\ Hospital General Regional No. 1 \\ ${ }^{2}$ Centro de Investigación Biomédica de Michoacán \\ Instituto Mexicano del Seguro Social (IMSS) \\ Morelia, Michoacán, México \\ ${ }^{3}$ Centro de Investigación Biomédica de Occidente, \\ Instituto Mexicano del Seguro Social (IMSS) \\ Guadalajara, Jalisco, México \\ ${ }^{4}$ Departamento de Postgrado \\ Facultad de Ciencias Médicas y Biológicas Dr. "Ignacio Chávez" \\ Universidad Michoacana de San Nicolás de Hidalgo (UMSNH) \\ Morelia, Michoacán, México \\ ${ }^{5}$ Coordinación de Investigación en Salud \\ Instituto Mexicano del Seguro Social (IMSS) \\ México City, México \\ ${ }^{6}$ Centro Multidisciplinario de Estudios en Biotecnología \\ Facultad de Veterinaria y Zootecnia, \\ Universidad Michoacana de San Nicolás de Hidalgo (UMSNH) \\ Morelia, Michoacán, México \\ ${ }^{7}$ Corresponding author: Tel, 52-443-3122880 Ext. 257; \\ Fax, 52-443-3122192; E-mail, calvareza@yahoo.com.mx
}

Accepted 19 March 2007

Abbreviations: ACE, angiotensin-1 converting enzyme; BMI, body mass index; CVD, cardiovascular disease; DBP, diastolic blood pressure; HDL-C, high density lipoprotein cholesterol; I/D, insertion/deletion; LDL-C, low density lipoprotein cholesterol; MS, metabolic syndrome; RAS, renin angiotensin system; SBP, systolic blood pressure; WC, waist circumference

\author{
Abstract \\ Metabolic Syndrome (MS) is recognized as a cluster \\ of cardiovascular risk factors. All components of MS
}

have a genetic base. Genes of the renin angiotensin system are potential candidate genes for MS. We investigated whether angiotensin converting enzyme (ACE) gene polymorphism increases susceptibility to MS as an entity in a Mexican population. In a cross-sectional study, 514 individuals were studied including 245 patients with MS and 269 subjects without MS criteria. ACE gene polymorphism was detected using PCR. MS was defined according to The National Cholesterol Education Program Expert Panel on Detection, Evaluation, and Treatment of High Blood Cholesterol in Adults (Adult Treatment Panel III) criteria, except that the raised fasting plasma glucose $\geq 100 \mathrm{mg} / \mathrm{dl}$ criterion for identification of intolerance fasting glucose was modified in accordance with the suggestion of the American Diabetes Association. Patients with MS were significantly different from subjects without MS in relation to mean body mass index (BMI), waist circumference (WC), systolic blood pressure, diastolic blood pressure, glucose, total cholesterol (C), triglycerides, HDL-C, and LDL-C $(P<0.0001)$. The differences in the mean BMI, WC, glucose, total cholesterol, triglycerides, LDL-C, and HDL-C were maintained in patients with the MS and DD genotypes $(P<0.01)$. The DD genotype was strongly associated with MS (adjusted OR = 5.48, 95\% Cl 3.20-9.38, $P<0.0001)$. We concluded that the DD genotype increases susceptibility to MS in a Mexican population. These results indicate that pharmacological and non-pharmacological treatment and a reduction in body fat will have important therapeutic im plications in this disease.

Keywords: metabolic syndrome $X$; obesity; peptidyldipeptidase $A$; polymorphism, genetic; renin-angiotensin system; risk factors

\section{Introduction}

Metabolic Syndrome (MS) is recognized as a cluster of cardiovascular risk factors that frequently coincide with central obesity, dyslipidemia, hypertension, and hyperglycemia (Timar et al., 2000) with a frequent occurrence in various ethnic groups. Its presence is associated with a high risk of developing cardiovascular disease (CVD) (Isomaa et al., 2001). 
Recent estimates show the prevalence of MS in the adult population as $32 \%$ for Hispanic Americans, $22 \%$ for Afro-Americans, and $24 \%$ for Caucasian populations (Ford et al., 2002). This prevalence increases more than $70 \%$ in patients with type 2 diabetes (llanne-Parikka et al., 2004). All components of MS have a genetic base (Scott et al., 2000). As a consequence, there is an interaction or multiplying effects of polymorphism in a growing number of genes potentially involved in this disease.

The renin angiotensin system (RAS) is a coordinated cascade that starts with the synthesis and secretion of renin from juxtaglomerular cells in the afferent renal artery (Boucher et al., 1977). The angiotensin converting enzyme (ACE) key for RAS catalyzes the conversion of angiotensin I to angiotensin II (Angll), a potent vasocontrictor, and promotes the degradation of bradykinin (Erdos and Skidgel, 1987). The insertion/deletion (I/D) polymorphism of the ACE gene is characterized by the presense (I) or absence (D) of an alu repetitive sequence of $287 \mathrm{bp}$ in intron 16 of the ACE gene. Individuals with the insertion (I) have a fragment of $490 \mathrm{bp}$ and individuals with the deletion (D) have a fragment of $190 \mathrm{bp}$ in PCR amplification (Rigat et al., 1992). The ACE gene is related to the inter-individual variability of plasma ACE levels. Individuals with the DD genotype have higher ACE plasma levels, compared with individuals with the II or I/D genotypes (Rigat et al., 1990).

RAS is essential in cardiovascular hemodynamics and plays an important role in the development of CVD (Harrap, 1996). Several studies have demonstrated that ACE gene polymorphism is a risk factor for ischemic cardiopathy (Ruiz et al., 1994), hypertension (Caulfield et al., 1994) and type 2 diabetes (Feng et al., 2002); however, cross-sectional studies have yielded conflicting results depending on several factors, including ethnic differences, sample size, and patient characteristics (Cambien et al., 1994; Iwai et al., 1994; Panahloo et al., 1995; Chiu and McCarty, 1997). Many studies have investigated the associations between genetic polymorphisms and the various components of MS. In contrast, few studies have explored this association with MS as an entity. Therefore, the aim of our study was to determine whether ACE polymorphism increases susceptibility to MS as an entity in a Mexican population.

\section{Materials and Methods}

\section{Patients}

Using a cross-sectional study from January 2005 to December 2005, we studied 514 individuals of both sexes including 245 patients with MS and 269 subjects without MS criteria. The sample size was calculated using a formula for cross-sectional studies with a confidence level of $95 \%$, an acceptable error of $\pm 2.3 \%$, and an expected proportion of patients with MS of $50 \%$ (Lwanga and Lemeshow, 1991). The calculated sample size was 473 patients plus $10 \%$ additional to cover for possible lost. All patients were born in the state of Michoacán, which is located in the central part of Mexico. All were mestizos in origin as a result of admixture between Europeans and Native Mexicans. All patients were treated at the Unidad de Medicina Familiar No. 80 Instituto Mexicano del Seguro Social (IMSS) in Morelia, Michoacán, Mexico. A complete clinical history of all patients was taken, including gender, age, body mass index (BMI), waist circumference (WC), systolic blood pressure (SBP), diastolic blood pressure (DBP) glucose, total cholesterol, triglycerides, high density lipoprotein cholesterol (HDL-C), and low density lipoprotein cholesterol (LDL-C). The BMI was calculated according to the Quetelet equation. Blood pressure was registered twice using a calibrated mercury Baumanometer (Model 88030054; Mercurial Sphygmomanometer, American Diagnostic Corp.) with the patient seated, at rest for at least $5 \mathrm{~min}$, without having ingested caffeinated drinks or having smoked cigarettes 30 min prior to the reading. The average of the two measurements was reported.

MS was defined according to The National Cholesterol Education Program Expert Panel on Detection, Evaluation, and Treatment of High Blood Cholesterol in Adults (Adult Treatment Panel III, ATP III) criteria. The definition in 2001 of ATP III identified a fasting plasma glucose level of $\geq 110 \mathrm{mg} / \mathrm{dl}$ as elevated. This definition was modified in 2004 to be $\geq 100 \mathrm{mg} / \mathrm{dl}$ according to the American Diabetes Association update of the definition of the intolerance fasting glucose level (IFG) (Grundy et al., 2004). MS was determined by the presence of at least three of the following abnormalities: central obesity (waist circumference $>102 \mathrm{~cm}$ in men or $>$ $88 \mathrm{~cm}$ in women), triglycerides $\geq 150 \mathrm{mg} / \mathrm{dl}$, or drug treatment for elevated triglycerides, HDL-C $<40$ $\mathrm{mg} / \mathrm{dl}$ in men or $<50 \mathrm{mg} / \mathrm{dl}$ in women or drug treatment for reduced HDL-C, blood pressure $\geq 130 / 85$ $\mathrm{mmHg}$ without antihypertensive treatment or with antihypertensive drug treatment in a patient with a history of hypertension, and raised IFP $\geq 100 \mathrm{mg} / \mathrm{dl}$ or previously diagnosed type 2 diabetes. Diabetes was defined according to the American Diabetes Association criteria and hypertension was defined according to the Seven Report of the Joint National Committee on Detection, Evaluation and Treatment of High Blood Pressure (DC report 2004; Chobanian et al., 2003). 
The protocol was approved by the Research and Ethics Committee of the Hospital General Regional No. 1, IMSS, Morelia, Michoacán, México. Informed consent for genetic studies was obtained from all patients.

\section{Biochemical measurements}

Glucose, total cholesterol, triglycerides, HDL-C, and LDL-C levels were measured in all subjects using equipment for chemical analysis (Dimension AR/ AVL Clinical Chemistry System, Newark, NJ).

Dyslipidemia was considered as a total cholesterol level of $\geq 200 \mathrm{mg} / \mathrm{dl}$, triglyceride $\geq 150$ $\mathrm{mg} / \mathrm{dl}$, low HDL-C $<40 \mathrm{mg} / \mathrm{dl}$ for men and $<50$ $\mathrm{mg} / \mathrm{dl}$ for women, and high LDL-C $\geq 130 \mathrm{mg} / \mathrm{dl}$ concentrations.

\section{DNA analysis and PCR}

DNA was extracted from leucocytes obtained from peripheral blood samples of the subjects using the technique of Miller et al. (1988) with minor modifications.

Two hundred $\mu$ l of blood was placed in a $1.5-\mathrm{ml}$ tube. Two hundred $\mu$ SDS at $1.6 \%$ was added, the immersion was mixed, and $80 \mu$ of lysozyme (20 $\mathrm{mg} / \mathrm{ml}$ ) was added to the mixture and left for 20 min at $37^{\circ} \mathrm{C}$. Next, $290 \mu$ of ammonium acetate $(7 \mathrm{M})$ was gently mixed and left for an additional $5 \mathrm{~min}$. Then, $770 \mu$ of phenol was added, the tube was shaken vigorously and centrifuged at 10,000 rpm. The excess was placed in another $1.5-\mathrm{ml}$ tube, 850 $\mu l$ absolute ethanol was added, the immersion was mixed, left for $5 \mathrm{~min}$ on ice, centrifuged at 10,000 rpm during $10 \mathrm{~min}$, dried and dissolved once again in $50 \mu$ of DNA stabilizing solution. The concentration was determined spectrophotometrically at 260 $\mathrm{nm}$ and the integrity of the DNA was checked by agarose gel electrophoresis $(1 \%)$ with $1 \times$ TAE buffer at $80 \mathrm{~V}$ and staining with ethidium bromide $(0.5$ $\mathrm{g} / \mathrm{ml})$.

PCR was performed at a final volume of $25 \mu$ with $100 \mathrm{ng}$ of genomic DNA, 50 pmol of each oligonucleotide of the ACE gene with the following sequences: sense 5'-CTGGAGACCACTCCCATCCTTTCT-3', antisense 5'-GATGTGGCCATCACATTCGTCAGAT-3' (Asamoah et al., 1996), $3 \mathrm{mM} \mathrm{MgCl}$, $2.5 \mu \mathrm{l}$ of $10 \times$ buffer $(100 \mathrm{mM} / \mathrm{KCl}, 100 \mathrm{mM} / \mathrm{l}$ Tris- $\mathrm{HCl}, \mathrm{pH} 8.3), 2 \mu \mathrm{l}$ of the mixture of dNTPs $(2.5$ $\mathrm{mM}), 1 \mathrm{U}$ of Taq polymerase and $25 \mu \mathrm{l}$ distilled, deionized water (cbp). Amplification was carried out in a thermocycler (Eppendorff, Mastercycler Gradient) with 30 cycles under the following conditions: $1 \mathrm{~min}$ at $94^{\circ} \mathrm{C}$ for denaturation, $1 \mathrm{~min}$ at $58^{\circ} \mathrm{C}$ for aligning and $2 \mathrm{~min}$ at $72^{\circ} \mathrm{C}$ for extension, and a final extension at $72^{\circ} \mathrm{C}$ for $5 \mathrm{~min}$. To exclude mistyping of heterozygotes, all DD homozygote samples were confirmed using a pair of specific flanked oligonucleotides for insertion with the following sequences: sense 5'-TGGGACCACAGCGCCCGCCACTAC-3', antisense 5'-TCGCCAGCCCTCCCATGCCCATAA-3' (Shanmugan et al., 1993). PCR products used were similar to the ones used for obtaining I/D except for the time and temperature of alignment, which was $45 \mathrm{~s}$ at $67^{\circ} \mathrm{C}$. PCR products were electrophoresed in $1 \%$ agarose gel and visualized by staining with ethidium bromide. Genotype II was characterized by a 490-bp band, genotype DD by a 190-bp band, and genotype ID by the presence of both bands.

\section{Statistical analysis}

Data are presented as mean $\pm S D$. The HardyWeinberg equilibrium was estimated by comparing observed and expected genotype frequencies of ACE gene polymorphism using $\chi^{2}$. Differences between and within-groups of the continuous variables were analyzed using Student's $t$-test, ANOVA and Tukey's post hoc test, respectively. Nominal variables were analyzed using $\chi^{2}$. A multiple logistic regression model was used to test the effect of ACE genotypes on the likelihood of MS while controlling the confounding effects of age and gender. The odds ratio (OR) together with the $95 \%$ confidence interval $(95 \% \mathrm{Cl})$ for the allelic frequency in the study

Table 1. Clinical and biochemical variables in individuals with and without metabolic syndrome.

\begin{tabular}{lcc}
\hline \multicolumn{1}{c}{ Variables } & $\begin{array}{c}\text { With metabolic } \\
\text { syndrome }\end{array}$ & $\begin{array}{c}\text { Without metabolic } \\
\text { syndrome }\end{array}$ \\
\hline$n(\%)$ & $245(47.7)$ & $269(52.3)$ \\
Gender (M/F) & $117 / 128$ & $127 / 142$ \\
Age (years) & $57 \pm 7$ & $58 \pm 9$ \\
BMl (kg/m $\left.{ }^{2}\right)$ & $30.0 \pm 3.2^{*}$ & $26.0 \pm 3.0$ \\
WC (cm) & $102.3 \pm 9.9^{*}$ & $85.1 \pm 8.7$ \\
SBP (mmHg) & $142 \pm 15^{*}$ & $131 \pm 18$ \\
DBP (mmHg) & $86 \pm 7^{*}$ & $81 \pm 8$ \\
Glucose (mg/dl) & $172.4 \pm 55.8^{*}$ & $83.4 \pm 10.7$ \\
Total cholesterol (mg/dl) & $243.3 \pm 52.6^{*}$ & $210.8 \pm 35.2$ \\
Triglycerides (mg/dl) & $181.2 \pm 63.6^{*}$ & $136.6 \pm 47.8$ \\
HDL-C (mg/dl) & $43.5 \pm 10.0^{*}$ & $49.5 \pm 11.1$ \\
LDL-C (mg/dl) & $153.3 \pm 28.4^{*}$ & $131.5 \pm 26.4$ \\
\hline
\end{tabular}

Data expressed as mean $\pm S D$. Gender is reported in number. $n$, Number of individuals; M, Male; F, Female. BMI, Body mass index [weight $(\mathrm{kg}) /$ height $\left(\mathrm{m}^{2}\right)$ ]; WC, Waist circumference; SBP, Systolic blood pressure; DBP, Diastolic blood pressure; HDL-C, HDL-Cholesterol. LDL-C: LDL-cholesterol. * $P<0.0001$. 
Table 2. Clinical and biochemical variables in individuals with and without metabolic syndrome analyzed for genotype.

\begin{tabular}{|c|c|c|c|c|c|c|}
\hline \multirow{3}{*}{ Variables } & \multicolumn{6}{|c|}{ ACE I/D genotype } \\
\hline & \multicolumn{3}{|c|}{ With metabolic syndrome } & \multicolumn{3}{|c|}{ Without metabolic syndrome } \\
\hline & II & ID & DD & II & ID & DD \\
\hline$n(\%)$ & $36(14.7)$ & $111(45.3)$ & $98(40.0)$ & $82(30.5)$ & $144(53.5)$ & $43(16.0)$ \\
\hline Gender (M/F) & $16 / 20$ & $57 / 54$ & $44 / 54$ & $39 / 43$ & $73 / 71$ & $15 / 28$ \\
\hline Age (years) & $56 \pm 9$ & $57 \pm 7$ & $58 \pm 6$ & $59 \pm 9$ & $57 \pm 7$ & $57 \pm 9$ \\
\hline $\mathrm{BMl}\left(\mathrm{kg} / \mathrm{m}^{2}\right)$ & $29.3 \pm 2.4$ & $29.0 \pm 2.7$ & $31.5 \pm 3.6^{*}$ & $25.5 \pm 2.9$ & $26.2 \pm 2.9$ & $25.9 \pm 3.4$ \\
\hline WC $(\mathrm{cm})$ & $99.2 \pm 10.9$ & $100.3 \pm 8.3$ & $105.6 \pm 10.3^{*}$ & $84.2 \pm 8.2$ & $85.4 \pm 8.8$ & $85.9 \pm 9.6$ \\
\hline $\mathrm{SBP}(\mathrm{mmHg})$ & $139 \pm 12$ & $141 \pm 14$ & $146 \pm 16$ & $129 \pm 17$ & $132 \pm 18$ & $131 \pm 21$ \\
\hline $\mathrm{DBP}(\mathrm{mmHg})$ & $85 \pm 8$ & $86 \pm 6$ & $87 \pm 8$ & $79 \pm 8$ & $82 \pm 8$ & $82 \pm 9$ \\
\hline Glucose (mg/dl) & $164.5 \pm 51.7$ & $161.9 \pm 50.3$ & $187.3 \pm 59.6^{*}$ & $83.6 \pm 10.3$ & $82.6 \pm 11.5$ & $84.3 \pm 11.2$ \\
\hline Total cholesterol (mg/dl) & $228.9 \pm 32.5$ & $232.9 \pm 47.0$ & $260.5 \pm 59.8^{*}$ & $213.4 \pm 32.2$ & $210.1 \pm 38.8$ & $207.5 \pm 24.1$ \\
\hline Triglycerides (mg/dl) & $159.4 \pm 34.8$ & $171.0 \pm 45.8$ & $200.7 \pm 81.9^{*}$ & $127.0 \pm 34.8$ & $140.7 \pm 48.4$ & $141.4 \pm 66.7$ \\
\hline $\mathrm{HDL}-\mathrm{C}(\mathrm{mg} / \mathrm{dl})$ & $48.4 \pm 12.0$ & $44.8 \pm 10.0$ & $40.3 \pm 8.1^{*}$ & $49.8 \pm 11.4$ & $49.1 \pm 10.6$ & $49.8 \pm 13.2$ \\
\hline LDL-C (mg/dl) & $141.7 \pm 18.0$ & $148.0 \pm 27.4$ & $164.0 \pm 29.6^{*}$ & $130.9 \pm 27.4$ & $130.9 \pm 27.4$ & $128.7 \pm 21.7$ \\
\hline
\end{tabular}

Data expressed as mean $\pm \mathrm{SD}$. Gender is reported in number. $\mathrm{n}$, Number of individuals; M, Male; F, Female; BMl, Body mass index [weight $(\mathrm{kg}) /$ height $\left(\mathrm{m}^{2}\right)$ ]. WC, Waist circumference; SBP, Systolic blood pressure; DBP, diastolic blood pressure; HDL-c, HDL-cholesterol; LDL-c, LDL-cholesterol; II, Insertion/Insertion; ID, Insertion/Deletion; DD, Deletion/Deletion. * $P<0.01$.

Table 3. Distribution of ACE genotype and allele frequencies in the individuals with and without metabolic syndrome.

\begin{tabular}{ccc}
\hline Variable & $\begin{array}{c}\text { With metabolic } \\
\text { syndrome } \\
(n=245)\end{array}$ & $\begin{array}{c}\text { Without metabolic } \\
\text { syndrome } \\
(n=269)\end{array}$ \\
\hline Genotypes & & \\
II & $36(14.7)^{*}$ & $82(30.5)$ \\
ID & $111(45.3)$ & $144(53.5)$ \\
DD & $98(40.0)^{*}$ & $43(16.0)$ \\
Alleles & & \\
I & $183(37.3)$ & $308(57.2)$ \\
D & $307(62.7)^{*}$ & $230(42.8)$ \\
\hline
\end{tabular}

Data are $n(\%)$. II, Insertion/Insertion; ID, Insertion/Deletion; DD, Deletion/ Deletion. ${ }^{*} P<0.0001$ compared with individuals without MS.

groups were calculated. A value of $P<0.05$ was considered statistically significant. SPSS software v.10.0 for Windows (Chicago, IL) and Stata software 8.0 special version (College Station, Texas), were used to perform statistical analyses.

\section{Results}

A total 514 subjects was included, 245 patients with
Table 4. Association of metabolic syndrome and polymorphism, adjusted by gender and ege.

\begin{tabular}{cccc}
\hline \multirow{2}{*}{ Genotype ratio } & Adjusted Odds & \multicolumn{2}{c}{$95 \% \mathrm{Cl}$} \\
\cline { 3 - 4 } & & Lower limit & Upper limit \\
\hline DD $^{*}$ & 5.48 & 3.20 & 9.38 \\
ID $^{* *}$ & 1.79 & 1.12 & 2.87 \\
\hline
\end{tabular}

The II genotype was considered as reference. ${ }^{*} P<0.0001 ;{ }^{* *} P=0.01$.

MS and 269 without MS criteria. Among the patients with MS, type 2 diabetes was found in $190(77.6 \%)$, hypertension in 155 (63.3\%), obesity in 138 (56.3\%), and dyslipidemia in $90(36.7 \%)$. In the subjects without MS, type 2 diabetes was found in $5(1.9 \%)$, hypertension in $65(24.2 \%)$, obesity $37(13.8 \%)$, and dyslipidemia in $11(4.1 \%)$.

Table 1 shows the clinical and biochemical variables in individuals with and without MS. Patients with MS were significantly different from subjects without MS in relation to the mean BMI, WC, systolic blood pressure (SBP), diastolic blood pressure (DBP), glucose, total cholesterol, triglycerides, HDL-C, and LDL-C $(P<0.0001)$. Differences in the mean BMI, WC, glucose, total cholesterol, triglycerides, HDL-C, and LDL-C, were maintained in patients with MS and the DD genotype in comparison with patients with 
A

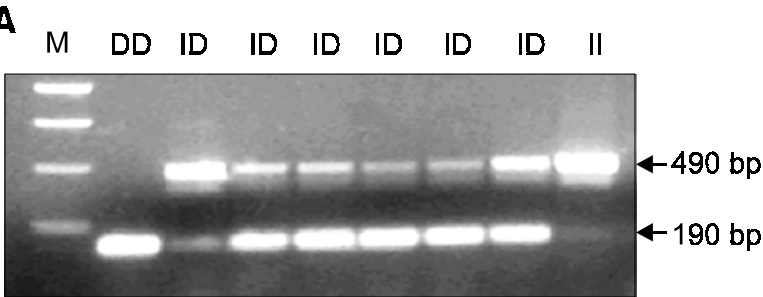

B

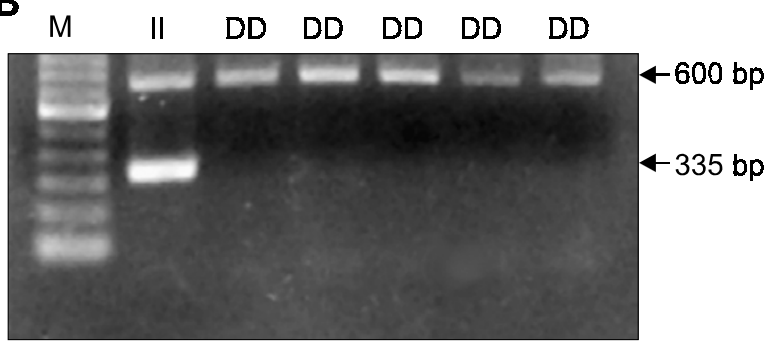

Figure 1. (A) Individuals homozygous for the $D$ allele (DD genotype) were identified by the presence of a single $190 \mathrm{bp}$ product. Individuals homozygous for the I allele (II genotype) were identified by the presence of a single $490 \mathrm{bp}$ product. Heterozygous individuals (ID genotype) were identified by the presence of both the $190 \mathrm{bp}$ and the 490 bp products. $\mathrm{M}=1 \mathrm{~kb}$ marker Benchtop, Promega. (B) The II homozygous state was identified by the presence of the $335 \mathrm{bp}$ product. $\mathrm{M}=$ 100 bp marker Invitrogen.

MS and either the II or ID genotypes of ACE gene polymorphism $(P<0.01$, Table 2$)$.

Table 3 shows the distribution of the ACE genotype and allele frequencies in individuals with and without MS. The DD genotype $(40.0 \%$ vs $16.0 \%, P$ $<0.0001)$ and the $D$ allele $(62.7 \%$ vs $42.8 \%, P<$ $0.0001)$ were significantly more frequent in patients with MS than without MS. In contrast, the II genotype (30.5\% vs $14.7 \%, P<0.0001)$ was more frequent in subjects without MS than with MS. The distributions of the ACE genotypes observed were in agreement with the Hardy-Weinberg equilibrium. Table 4 shows the multiple logistic regression model adjusting for the confounding effects of gender and age. The results revealed a strong association of the DD genotype with MS (adjusted OR 5.48, 95\% Cl 3.20-9.38, $P<0.0001)$. These results indicate that subjects with the DD genotype have an increased susceptibility for developing MS. Figure 1 shows representative gel images of the ACE gene.

\section{Discussion}

We examined the relationship between ACE gene polymorphism in 245 patients with MS and 269 subjects without MS using the ATP III criteria with modification in the IFG criteria in accordance with the American Diabetes Association's (Grundy et al., 2004).

Our study reveals that the DD genotype is strongly associated with an increased susceptibility to MS as an entity. To our knowledge this is the first study that shows a relationship between ACE gene polymorphism with MS in a Mexican population. Our results are in accordance with a previous study in other populations (Lee et al., 2002) that has shown that the DD genotype confers an increased risk for MS. In a large Chinese population-based study with type 2 diabetes using the 1998 World Health Organization (WHO) criteria for diagnosis of MS, the DD genotype was associated with increased risks for MS, dyslipidemia, and albuminuria. In contrast, in other studies (Costa et al., 2002) performed in a Brazilian population of European ancestry selfclassified as white with type 2 diabetes and MS using the WHO criteria, an association between ACE gene I/D polymorphism and MS was not found. The reasons for this discrepancy is not known. One possible explanation is ethnic differences. It is well known that the allele frecuency of ACE gene polymorphism varies according to ethnic group (Barley et al., 1994). The DD genotype is more frequent in a Caucasian population than in an Asian population. In the Mexican population, mestizas comprise $80 \%$ of the total, with $20 \%$ corresponding to Mexican Indian groups and a reduced group (less than $1.0 \%$ ) of a white population formed by inmigrant Europeans (mainly Spanish) and North-Americans (from the United States of America and Canada). A Mexican mestizo has been defined by the National Institute of Anthropology as a person who was born in the country, has a Spanish-derived last name, and a family of Mexican ancestors of at least three generations (Gorodezky et al., 2001). Our results support this hypothesis because a high prevalence of the DD genotype has been reported in previous studies in a Spanish population with nephropathy (Ortiz et al., 2003). Another explanation may be related to possible interactions with other genes or enviromental factors, although further study is necessary to verify this explanation. Previously, Zhu et al. (2003) performed genotyping of single-nucleotide polymorphisms in the RAS genes ACE, angiotensinogen (AGT) angiotensin II receptor, subtype 1 (AGTR1), and renin in a biracial population sample. Evidence was found that inter-individual variation in the RAS genes contributes to a hypertension risk. Marre et al. (1997) studied the contribution of genetic polymorphism in RAS to the development of renal complications in insulin-dependent diabetes in a European population.

It is difficult to provide explanation of a mecha- 
nism by which ACE gene polymorphism promotes susceptibility to MS. One possible explanation is related to participation of RAS in the components of MS. It is generally accepted that RAS participates in the long-term complications of diabetes (Gilbert et al., 2003) and previous findings have reported an association of the DD genotype with the development of type 2 diabetes in several populations (Feng et al., 2002; Lee and Tsai, 2002; Ergen et al., 2004).

We found that patients with the MS and DD genotypes were associated with obesity. These results are interesting because of the strong association between RAS and the mechanisms of obesity. Obesity leads to hypertension and increases the cardiovascular risk (Mikhail et al., 1999). RAS has been implicated in obesity by several authors (Giacchetti et al., 2002), which is supported by recent investigations that show high plasma concentrations of angiotensinogen (ANG) (Umemura et al., 1997) and a rise in the expression of the ANG gene in obese humans (Van Harmelen et al., 2000). The plasma ANG decrease was highly correlated with the WC decline and with one reduction in the systolic ambulatory blood pressure (Engeli et al., 2005). These data suggest that a reduction in body weight can lead to a reduced RAS in plasma and adipose tissue. In addition, targeted expression of 11 $\beta$-hidroxyesteroid dehydrogenase-1 (11- $\beta$-HSD1) in adipocytes and a direct relationship with obesity have been recently reported. In adipocytes, 11- $\beta$ HSD1 caused an increased plasma AGT level and increased blood pressure. In adipose tissue, the AGT gene was expressed in mice with a wild-type generic background (Alsaeid et al., 2004). Higher ACE activity in obese individuals and a decrease in ACE activity with weight loss have been described previously (Keidar et al., 1994) as has the DD genotype predicting central obesity and an increase in body weight and blood pressure with aging in men (Keidar et al., 1996). The DD genotype has influence on blood pressure and body weight.

Dyslipidemia in MS is characterized by an increase in triglycerides, LDL-C, and low HDL-C. These alterations contribute to an increase in the risk for CVD in individuals with MS. We found a relationship between dyslipidemia and ACE gene polymorphism with the DD genotype in patients with MS. This is related to previous studies that identified the DD genotype in patients with type 1 (Masuzaki et al., 2003) and type 2 diabetes (Lee and Tsai, 2002), showing the important role of RAS as a likely contributor to MS. Experiments in vitro have suggested that ANG participates in the growth, development, and metabolic functioning of fatty tissue once it is converted into Ang II, which connects specifically to LDL-C (Harp et al., 2002) and produces another modified form of LDL-C that is captured by the macrophage. This provokes an accumulation of cholesterol (Strazzullo et al., 2003).

Other possibility that may have significant clinical implications is the insulin resistance (IR) that appears to be a central feature of this syndrome associated with type 2 diabetes, obesity, dyslipidemia, hypertension, and recently with hypercoagulability, inflammation, atherosclerosis, and CVD (Dandona et al., 2002; Festa et al., 2002; Doelle, 2004). RAS has been implicated in IR as RAS inhibits the metabolic actions of insulin and promotes its proliferative effects for cellular interactions with the signal transduction pathways. These pathways include the phosphatidylinositol 3 and MAPK pathways that are dependent on tyrosine phosphorylation of insulin receptor sustrates 1 and 2 after binding to their respective receptors (Prasad and Quyyumi, 2004). However, the principal relationship between IR, ACE plasma levels, and the DD genotype in patients with MS requires more study in this and other populations.

In conclusion, we present evidence that the DD genotype of the ACE gene increases susceptibility to the MS entity in a Mexican population, providing genetic evidence of MS components in the Mexican population and an increased risk for CVD. These results indicate that pharmacological and non-pharmacological treatment and a reduction of body fat will have important therapeutic implications for this disease.

Additional studies will be necessary for investigating the association between the ACE gene and energy metabolism, vascular disregulation, the proinflamatory state, the prothrombothic state, and hormonal factors.

\section{Acknowledgment}

This study was sponsored by the Coordinación de Investigación Médica, Instituto Mexicano del Seguro Social grant No.2002/093. We extend our gratitude to Dr. Sergio Flores Hernández for his valuable guidance in the statistical analysis.

\section{References}

Alsaeid M, Moussa MAA, Haider MZ, Refai TM, Abdella N, Al-Sheikh N, Gomez JE. Angiotensin converting enzyme gene polymorphism and the lipid profiles in Kuwaiti children with type 1 diabetes. Pediatr Diabetes 2004;5:87-94

Asamoah A, Yanamandra K, Thurmon TF, Richter R, Green $\mathrm{R}$, Lakin T, Martin C. A deletion in the angiotensin converting enzyme (ACE) gene is common among African Americans with essential hypertension. Clin Chem Acta 1996;254:41-6 
Barley J, Blackwood A, Carter ND, Crews DE, Cruickshank JK, Jeffery S, Ogunlesi AO. Sagnella GA. Angiotensin converting enzyme insertion/deletion polymorphism: association with ethnic origin. J Hypertens 1994;12:955-7

Boucher R, Rojo-Ortega JM, Genest J. Description of reninangiotensin system and methods of measurement. In Hypertension (Genest T, Koiw E, Kuchel O, eds), Hypertension, 1977, 140-154, McGraw-Hill, New York

Cambien F, Costerousse O, Tiret L, Poirier O, Lecerf L, Gonzales MF, Evans A, Arveiler D, Cambou JP, Luc G. Plasma levels and gene polymorphism of angiotensin-converting enzyme in relation to myocardial infarction. Circulation 1994;90:669-76

Caulfield M, Lavender P, Farral M, Munroe P, Lawson M, Turner $P$, Clark AJ. Linkage of the angiotensinogen gene to essential hypertension. N Engl J Med 1994;330:1629-32

Chiu KC, McCarty JE. The insertion allele at the angiotensin I-converting enzyme gene locus is associated with insulin resistance. Metabolism 1997;46:395-9

Chobanian AV, Bakris GL, Black HR, Cushman WC, Green LA, Izzo JL Jr, Jones DW, Materson BJ, Oparil S, Wright JT Jr, Roccella EJ. The Seventh Report of the Joint National Committee on Prevention, Detection, Evaluation, and Treatment of High Blood Pressure: the JNC 7 report. JAMA 2003;289:2560-72

Costa LA, Canani LH, Maia AL, Gross JL. The ACE insertion/ deletion polymorphism is not associated with the metabolic syndrome (WHO definition) in Brazilian type 2 diabetic patients. Diabetes Care 2002;25:2365-6

Dandona P, Aljada A, Mohanty P. The anti-inflammatory and potential anti-atherogenic effect of insulin:a new paradigm. Diabetologia 2002;45:924-30

Diagnosis and Classification of Diabetes Mellitus. American Diabetes Association. Diabetes Care 2004;27(Suppl 1):S510

Doelle GC. The clinical picture of metabolic syndrome: an update on this complex of conditions and risk factors. Postgrad Med 2004;116:30-8

Engeli S, Böhnke J, Gorzelniak K, Janke J, Schling P, Bader $M$, Luft FC, Sharma AM. Weight loss and the renin-angiotensin-aldosterone system. Hypertension 2005;45:356-62

Erdos GE, Skidgel AR. The angiotensin I-converting enzyme. Lab Invest 1987;56:345-8

Ergen HA, Hatemi $H$, Agachan B, Camlica $H$, Isbir $T$. Angiotensin-I converting enzyme gene polymorphism in Turkish type 2 diabetic patients. Exp Mol Med 2004;36:345-50

Executive Summary of the Third Report of the National Cholesterol Education Program (NCEP). Expert Panel on Detection, Evaluation, and Treatment of High Blood Cholesterol in Adults (Adults Treatment Panel III). JAMA 2001;285:2486-97

Feng Y, Niu T, Xu X, Chen C, Li Q, Qian R, Wang G, Xu X. Insertion/deletion polymorphism of the ACE gene is associated with type 2 diabetes. Diabetes 2002;51:1986-8

Festa A, D'Agostino R Jr, Tracy RP , Haffner SM. Elevated levels on acute-phase proteins and plasminogen activator inhibitor-1 predict the development of type 2 diabetes: The Insulin Resistance Atherosclerosis Study. Diabetes 2002;51: 1131-7

Ford ES, Giles WH, Dietz WH. Prevalence of the metabolic syndrome among US adults: findings from the third national health and nutrition examination survey. JAMA 2002;16:356-9

Giacchetti G, Faloia E, Mariniello B, Sardu C, Gatti C, Camilloni MA, Guerrieri M, Montero F. Overexpression of the reninangiotensin system in human visceral adipose tissue in normal and overweight subjects. Am J Hypertens 2002;15:381-8

Gilbert RE, Krum H, Wilkinson-Berka J, Kelly DJ. The renin-angiotensin system and the long-term complications of diabetes: pathophysiological and therapeutic considerations. Diabet Med 2003;20:607-21

Gorodezky C, Alaez C, Vazquez-Garcia MN, de la Rosa G, Infante E, Balladares S, Toribio R, Perez-Luque E, Munoz L. The genetic structure of Mexican Mestizos of different locations: tracking back their origins through $\mathrm{MHC}$ genes, blood group systems, and microsatellites. Hum Immunol 2001;62:979-91

Grundy SM, Hansen B, Smith SC Jr, Cleeman JI, Kahn RA; American Heart Association; National Heart, Lung, and Blood Institute; American Diabetes Association. Clinical management of metabolic syndrome: report of the American Heart Association/National Heart, Lung, and Blood Institute/American Diabetes Association conference on cientific issues related to management. Circulation 2004;109:551-6

Harp JB, Henry SA, DiGirolamo M. Dietary weight loss decreases serum angiotensin-converting enzyme activity in obese adults. Obes Res 2002;10:985-90

Harrap SB. Cardiovascular disease and genetics of the renin-angiotensin system. Heart 1996;76(Suppl 3):13-7

Ilanne-Parikka P, Eriksson JG, Lindstrom J, Hamalainen H, Keinanen-Kiukaanniemi S, Lalkso M, Louheranta A, Mannelin M, Rastas M, Salminen V, Aunola S, Sundvall J, Valle T, Lahtela J, Uusitupa M, Tuomilehto J. Prevalence of metabolic syndrome and its components: findings from a Finnish general population sample and the Diabetes Prevention Study Cohort. Diabetes Care 2004;27:2135-40

Isomaa B, Almgren P, Tuomi T, Forsén B, Lahti K, Nissén M, Taskinen MR, Groop L. Cardiovascular morbidity and mortality associated with the metabolic syndrome. Diabetes Care 2001;24:683-9

Iwai N, Ohmichi N, Nakamura Y, Kinoshita M. DD genotype of the angiotensin converting enzyme gene is a risk factor to left ventricular hypertrophy. Circulation 1994;90:2622-8

Keidar S, Kaplan M, Shapira C, Brook JG, Aviram M. Low density lipoprotein isolated from patients with essential hypertension exhibits increased propensity for oxidation and enhanced uptake by macrophages: a possible role for angiotensin II. Atherosclerosis 1994;107:71-84

Keidar S, Kaplan M, Aviram M. Angiotensin II-modified LDL is taken up by macrophages via scavenger receptor, leading to cellular cholesterol accumulation. Arterioescler Thromb Vasc Biol 1996;16:97-105 
Lee YJ, Tsai JCR. ACE gene insertion/deletion polymorphism associated with 1998 World Health Organization definition of metabolic syndrome in Chinese type 2 diabetic patients. Diabetes Care 2002;25:1002-8

Lwanga SK. Lemeshow S. Tamano de muestra para calculo de una proporción con precisión absoluta específica. In Determinación del Tamaño de las Muestras en los Estudios sanitarios, 1991, 12-26, World Health Organization, Geneva

Marre M, Jeunemaitre X, Gallois Y, Rodier M, Chatellier G, Sert C, Disselier L, Kahal Z, Chaillous L, Halimi S, Muller A, Sackmann H, Bauduceau B, Bled F, Passa P, Alhenc-Gelas $F$. Contribution of genetic polymorphism in the reninangiotensin system to the development of renal complications in insulin-dependent diabetes. J Clin Invest 1997;99:1585-95

Masuzaki H, Yamamoto $\mathrm{H}$, Kenyon CJ, Elsquist JK, Morton NM, Peterson JM, Shinyama H, Sharp MGF, Fleming S, Mullins JJ, SeckI JR, Flier JS. Transgenic amplification of glucocorticoid action in dipose tissue causes high blood pressure in mice. J Clin Invest 2003;112:83-90

Mikhail N, Golub MS, Tuck ML. Obesity and hypertension. Prog Cardivasc Dis 1999;42:39-58

Miller SA, Dykes DD, Polesky HF. A simple salting out procedure for extracting DNA from human nucleated cells. Nucleic Acids Res 1988;16:1215

Ortiz MA, De Prado A, Donate T, Gallart L, Claramunt H, Hernandez M, Martinez J, Martinez E, Pou JM. Angiotensinconverting enzyme polymorphism gene and evolution of nephropathy to end-stage renal disease. Nephrology 2003;8: 171-6

Panahloo A, Andres C, Mohamed-Ali V, Gould MM, Talmud P, Humphries SE. Yudkin JS. The insertion allele of the ACE gene I/D polymorphism. A candidate gene for insulin resistance? Circulation 1995;92:3390-3

Prasad A, Quyyumi AA. Renin-angiotensin system and angiotensin receptor blockers in the metabolic syndrome. Circulation 2004;110:1507-12

Rigat B, Hubert C, Alhenc-Gelas A, Cambien F, Corvol P,
Soubrier $F$. An insertion/deletion polymorphism in the angiotensin l-converting-enzyme (ACE) gene accounting for half the variance of serum enzyme levels. J Clin Invest 1990;86:1343-6

Rigat B, Hubert C, Corvol P, Soubrier F. PCR detection of the insertion/deletion polymorphism of the human angiotensin converting enzyme gene (DCP1) (dipeptidyl carboxypeptidase 1). Nucleic Acids Res 1992;20:1433

Ruiz J, Blanché H, Cohen N, Velho G, Cambien F, Cohen D, Passa $P$, Froguel P. Insertion/deletion polymorphism of the angiotensin-converting enzyme gene is strongly associated with coronary heart disease in non-insulin-dependent diabetes mellitus. Proc Natl Acad Sci USA 1994;91:3662-5

Scott J, Shoulders C, Navaratnam N, Aitman T. The genetics of the metabolic overlap syndrome. Proc Nutr Soc 2000;59: 439

Shanmugan V, Sell KW, Saha BK. Mistyping ACE heterozygotes. PCR Methods Appl 1993;3:120-1

Strazzullo P, lacone R, lacoviello L, Russo O, Barba G, Russo P, D'Orazio A, Barbato A, Cappuccio FP, Farinaro E, Siani A. Genetic variation in the renin-angiotensin system and abdominal adiposity in men: the Olivetti Prospective Heart Study. Ann Intern Med 2003;138:17-23

Timar O, Sestier F, Levy E. Metabolic syndrome X: a review. Can J Cardiol 2000;16:779-89

Umemura S, Nyui N, Tamura K, Hibi K, Yamaguchi S, Nakamaru M, Ishigami T, Yabana M, Kihara M, Inoue S, Ishii M. Plasma angiotensinogen concentrations in obese patients. Am J Hypertens 1997;10:629-33

Van Harmelen V, Ariapart P, Hoffstedt J, Lundkvist I, Bringman $S$, Arner $\mathrm{P}$. Increased adipose angiotensinogen gene expression in human obesity. Obes Res 2000;8:337-41

Zhu X, Chang CYP, Yan D, Weder A, Cooper R, Luke A, Kan $D$, Chakravarti A. Associations between hypertension and genes in the renin-angiotensin system. Hypertension 2003; 41:1027-34 